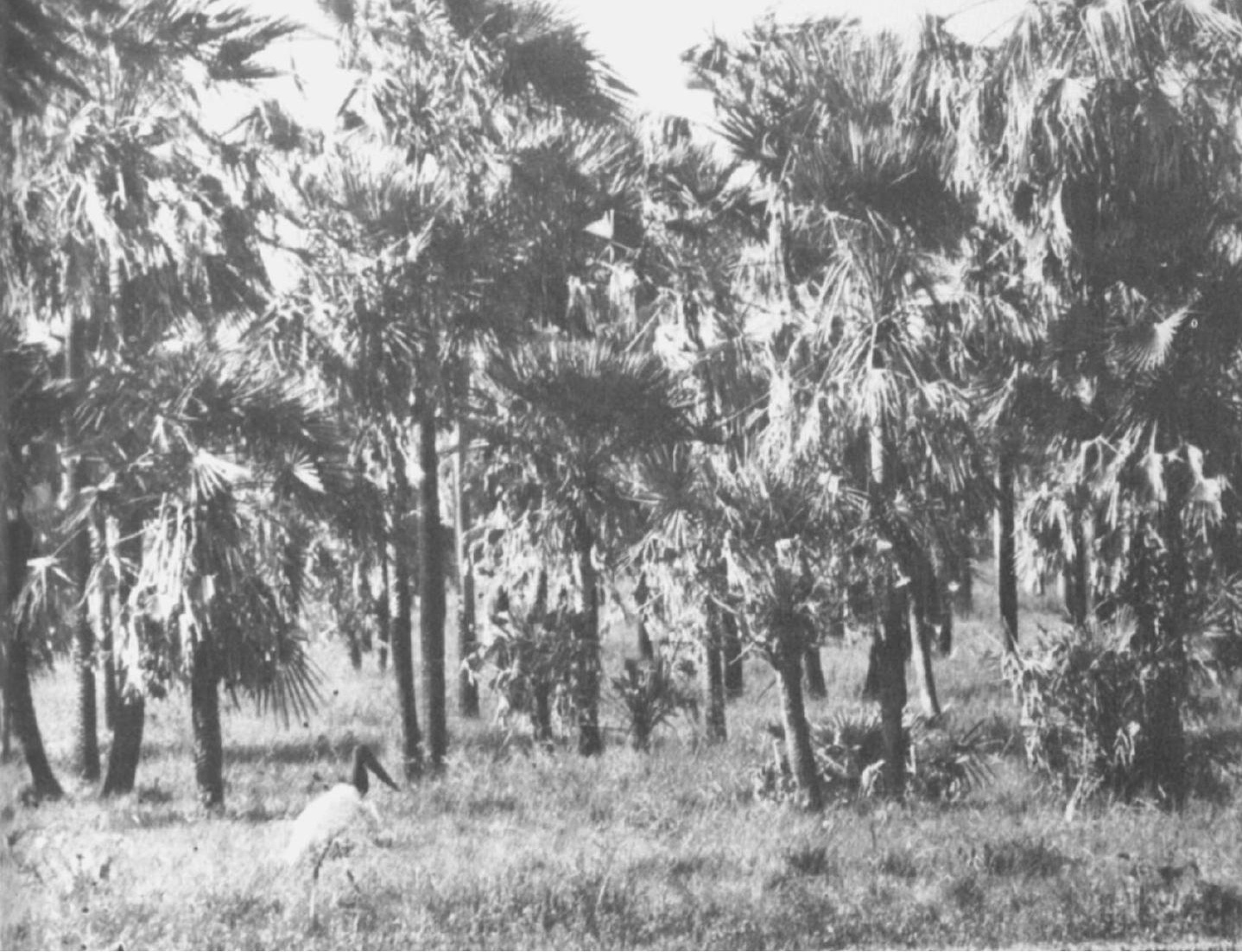

\title{
Saving Paraguay's Wilderness
}

\author{
Jacques Verschuren
}

Paraguay still has a vast area of almost undisturbed forest and savanna in the region known as the Chaco, where three large national parks, totalling over $1 \frac{1}{2}$ million hectares, protect a fauna that includes jaguar, puma, ocelot and a peccary that was 'rediscovered' in 1975. In 1979 the author, who is widely known as a scientist and conservationist, spent two months in Paraguay investigating the wildlife situation and national parks and has made recommendations for conservation measures to the Government.

Little is ever heard about wildlife conservation in Paraguay, although the country boasts one of the world's least disturbed areas, the refuge of an abundant wildlife. This is the semi-xerophile forest of the Chaco, of which in Paraguay about 20 million hectares are still intact - in neighbouring Argentina and Bolivia the Chaco is being rapidly destoyed - but cultivation is advancing fast. In its national parks Paraguay protects three important mammals of the American continent: jaguar, the largest cat, tapir, the largest ungulate, and Wagner's peccary Catagonus wagneri, a suid which, until it was recently 'rediscovered', was believed to have become extinct in the Pleistocene age.

In August and September 1979 I was able to visit a large part of Paraguay, Above: Copernicia palms typical of the humid Chaco, with a jabiru stork in the foreground. 


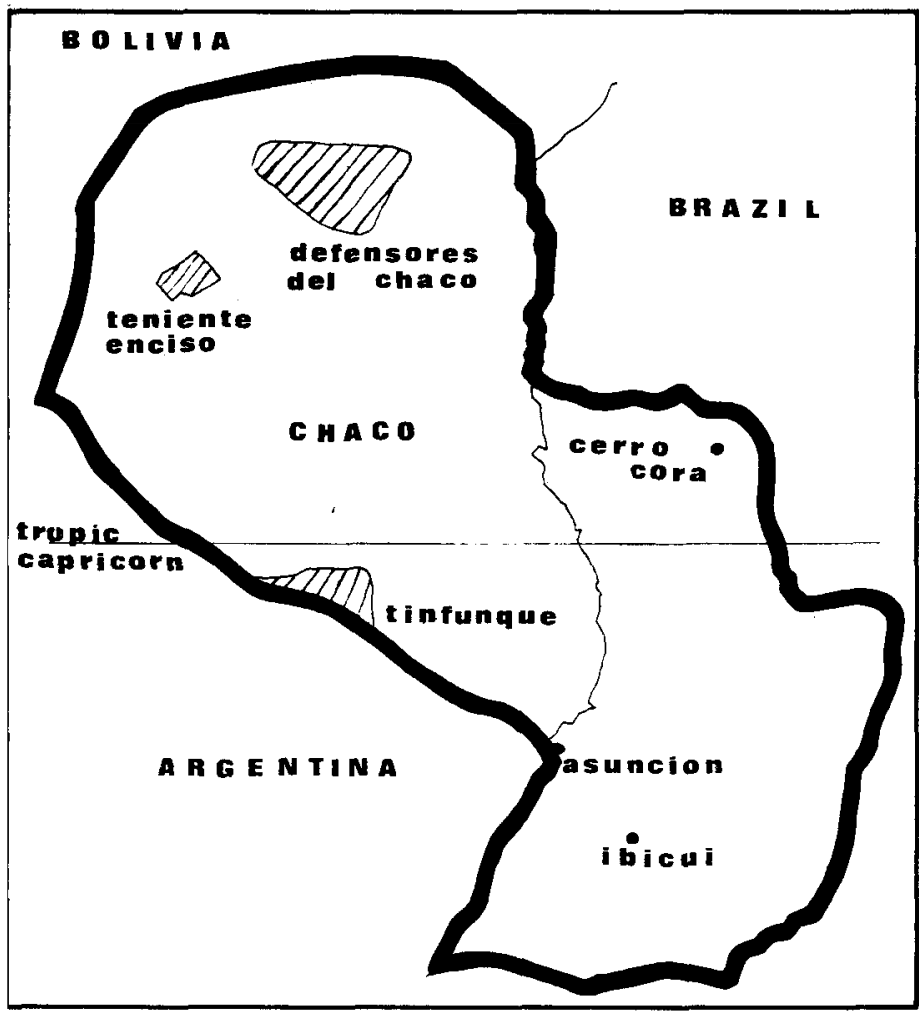

OPPOSITE

Top: A three-banded armadillo Tolypeutes matacus in defensive position, and a Chaco fox Dusicyon gymnocercus Below: One of the famous bottle trees; a coati Nasua nasua, abundant in Parque Nacional Defensores del Chaco; and a Chaco deer Mazama gouazoubira, also quite common

mainly the Chaco, investigating the development of national parks, within the framework of Belgian-Paraguayan co-operation.

Paraguay covers an area of $406,000 \mathrm{sq} \mathrm{km}$ on the Tropic of Capricorn. The inhabited part of the country lies to the east of Rio Paraguay; to the west is the Chaco, where in many areas the human population approaches $0 / \mathrm{sq} \mathrm{km}$. A few groups of Moro Indians from Cerro Leone survive, resisting integration with other groups, and are respected by the authorities.

In the south is the 'humid' Chaco with higher rainfall and a savanna dominated by Copernicia palms. The dry Chaco is a xerophile forest, one of the world's most 'closed' forest types and fire resistant. Typical species include the quebracho Aspidisperma quebracho and Schinopsis balansae, with extraordinarily tough wood, palo santo Bulnesia sarmienti, or incense tree, and the 'bottle trees'. In this relatively flat land there is little or no permanent flowing water, but this does not seem to restrict the wildlife, except in years of severe drought.

Forestry and conservation are in the charge of the Ministry of Agriculture, which has a National Parks and Wildlife Service (Departamento Manejo de Bosques, Parques Nacionales y Vida Silvestre), but the Chaco is administered by the Ministry of National Defence. Officially, hunting has been banned throughout the country since 1975; in practice this moratorium is observed hardly at all, although the native people are not traditionally hunters. Several species are threatened, and there is a significant traffic in skins, especially of cats. Despite having signed the CITES in April 1975, and ratified it in February 1977, Paraguay has taken no steps to put it into practice. However, recent contacts between Paraguay and IUCN and other organisations, particularly FAO, suggest that there may now be grounds for optimism. 

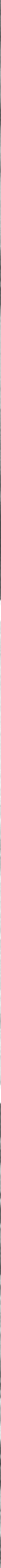
The national parks in the eastern part of the country (Cerro Cora, Ybicui, etc.) are small with only local interest. But in the Chaco Paraguay protects large examples of the principal natural features - in the humid zone by the Tinfunque National Park $(270,000$ ha) along the river Pilcomayo, where protection is due more to isolation than to supervision, and aquatic birds thrive, and in the ultra-dry zone (rainfall below $400 \mathrm{~mm}$ ) by the Teniente Enciso National Park, now probably being enlarged to 150,000 hectares.

The most important reserve, however, and one of world-wide interest, is the Defensores del Chaco National Park, in the north-north-east of the country, which protects 900,000 hectares of intact typical Chaco habitat and is one of South America's major wilderness areas. This has no natural frontiers, but sharp 'picadas' are often impenetrable, even to oil prospectors (investigations so far have found nothing). The Cerro Leone massif, although it only rises to 400 metres, is the only undulation. The climate is more temperate than sub-tropical, with temperatures below freezing in spite of low altitude and latitude $\left(20^{\circ}\right.$ to $\left.22^{\circ} \mathrm{S}\right)$. In the rainy season the park administration at Agua dulce is inaccessible, but a good airstrip links it with Asunción, the capital. Until recently there were no human inhabitants at all in the area. But modern techniques make cultivation extremely easy.

The vegetation is typical of the Chaco; it appears to be 95 per cent homogeneous, the trees decreasing in size towards the west and Cactaceae increasing in number. Open grassy areas, some swampy, some dry, constitute not more than one per cent of the park.

The park's chief interest is the large mammals. The commonest ungulate is the small Chaco deer Mazama gouazoubira, which has a considerable range; usually one or two are to be seen on every $5 \mathrm{~km}$ of track, and it occurs throughout the park. For the marsh deer Blastocerus dichotomus prospects are poor. With the installation of a large dam, the entire island of Yacireta in southern Paraguay, an important reserve for this deer, will be submerged. Rescue projects are proposed.

The typical large ungulate is the tapir Tapirus terrestris, which is strictly nocturnal and rarely seen. But tracks and excrement are abundant throughout the reserve, and the species seems safe here at least in the short term, despite a certain amount of poaching along the park borders. Of the three peccary species that occur, two, the common tayassu Tayassu tajacu and $T$. pecari, are hunted actively by the Indians and other poachers; remains can be seen in all the camps. The park is also a refuge - especially in the driest western part - for the 'new' peccary Catagonus wagneri, whose rediscovery in 1975 by Wetzel and his colleagues caused a sensation among zoologists. Known and described from its fossil remains, it was thought to have become extinct in the Pleistocene, but it must have been able to maintain its numbers in the driest part of the Chaco. It will also be protected in the drier Taniento Enciso National Park now being established, where it is undoubtedly commoner. In parts of the northern Chaco it is also common, but it is hunted indiscriminately along with the other peccaries and needs to be protected, although enforcement will be difficult. Guanaco Lama guanicoe is said to occur in the Defensores del Chaco Park but we regard this as doubtful.

The park protects six cat species, and they must still be quite common, for prey is abundant and tracks and other indirect signs are frequently seen. Ocelot $F$ elis pardalis and puma $F$. concolor are frequently seen, and we were 
able to observe puma in excellent conditions in the west of the park, near Langerenza. Jaguars $F$. onca, the most spectacular cat and third largest on earth, are not rare - there are thought to be over 100 in the park. Two were living in the immediate surroundings of the central station of Agua dulce, and another frequented the environs of Agua rica, $25 \mathrm{~km}$ to the west. They benefit from a plentiful food supply and are protected by the park's total inaccessibility. Poaching certainly occurs, and skins are exported frequently to Bolivia.

Other carnivores include the Chaco fox Dusicyon gymnocercus and the coati Nasua nasua, both quite common. Five armadillos include the giant armadillo Priodontes giganteus. The three-banded Tolypeutes matacus, which is everywhere, and the nine-banded Dasypus novemcinctus, sought after by man for its edible flesh, are the commonest, and are effectively protected by the park's size and inaccessibility. The giant anteater Myremecophaga gigantea, which I did not see, is not uncommon.

\section{Myriads of Birds}

Birds are protected in large numbers in the Chaco parks. Paraguay is remarkable in that birds, even birds of prey, are very little hunted; to a zoologist coming from West Africa, where wildlife is massacred, the birds seem disconcertingly tame. Myriads of aquatic birds can be seen from the trans-Chaco road, notably ibis, and even jabirus Fabiru mycteria and flamingoes Phoenicopterus chilensis, which are said to be decreasing. Black vultures Coragyps atratus are abundant throughout Paraguay and never harmed by the people. One large endemic bird is the chachalaca Ortalis canicollis, a large cracid, very conspicuous and vulnerable, but still common. The most typical water bird of northern Chaco is the plumbeous ibis Harpiprion caerulescens, which occurs in large numbers on all open waters. The nacunda nighthawk Podager nacunda is common on migration. The most interesting stretch of water in the north is probably the large marsh at the southern end of the Cerro Leone massif, where aquatic birds, especially cormorants, are abundant.

Paraguay's national parks have many difficult problems; in my report to the Government I have submitted my suggestions for making conservation more effective. Specialists from FAO and some American biologists have also made recommendations.

Is the area covered by the Chaco National Parks sufficient? At first glance about 1,400,000 hectares seems a considerable size, but it represents only 10 per cent of the total Chaco area in Paraguay. This percentage is relatively small, especially as within two or three decades the whole unprotected Chaco will inevitably be cultivated. Conservationists would be happier if the area initially set aside for the Defensores del Chaco park (some 2,000,000 hectares) had been adhered to. The whole area between the park's northern boundary $\left(20^{\circ} \mathrm{S}\right)$ and the Bolivian border will soon be cultivated, but vast, completely intact areas remain on the southern boundary.

Poaching is still a worrying problem. Traditional hunting by the Moro Indians can be tolerated - but how long will it remain traditional? Foreigners, non-'traditional' Indians and soldiers, are the chief poachers, and their numbers can only increase with the settlement envisaged for the northern areas. Most threatened are the cats, for hunters and international traffickers increasingly realise that northern Paraguay constitutes one of the last 'game' 
areas of South America, and the pressure mounts. At the moment, control of all trade in wildlife takes priority. The role of CITES is vital in this respect. Control measures - less draconian perhaps than the theoretical moratorium on all hunting - are urgent.

Inadequate supervision is a major problem. The number of guards is derisory, and it is a top priority that fifteen wardens should be based at the four guard posts - Agua dulce, Madrejon, Langerenza, Cerra Leone - all with uniforms and tough equipment, including several strong solid vehicles. Proper sanctions should be taken against delinquents, and 'buffer zones' established along the park borders. The water point at the Agua dulce headquarters may be contested by settlers.

However, the interest in conservation shown by the highest authorities in the country, including the Ministries of Defence and Agriculture, is most encouraging. The Paraguayan press devotes a lot of space to conservation problems. It is certainly not too late for the Paraguayan Chaco and its remarkable wildlife to be saved.

Dr Jacques Verschuren, Institut Royal des Sciences Naturelles de Belgique, 31, rue Vautier, Bruxelles 1040, Belgium.

\section{Lynx in Europe - Some Reintroductions}

Several successful reintroductions of European lynx have been made - notably in Switzerland in 1970, where there are now 30-40 animals, Yugoslavia, where six introduced in 1973 have since bred, and Austria, where nine introduced in 1977/78 have also bred. Professor Antal Festetics, of Göttingen University describes the careful planning preparations and monitoring needed to ensure success. For the Austrian introduction three years were spent in finding a suitably large and ecologically intact area and getting the cooperation of landowners. A large enclosure was made and nine lynx, captured in Czechoslovakia, were released into it to be acclimatised; before release they were fitted with miniature radio transmitters, and two staff members were then continuously employed checking their movements and following them - on foot, by car, even in a light aeroplane, and, after the first snowfall, on skis. The lynx settled in quickly, neither exterminating the deer (as some hunters feared) nor reducing their numbers (as some foresters hoped). In fact, of course, the effect of these predators on their prey species is primarily, as Dr Festetics points out, 'not quantitative but qualitative', selection rather than regulation, and thus beneficial to the prey species.

\section{New Dragonfly Group}

Kyoto in Japan was a particularly suitable place in which to hold the inaugural meeting of the SSC Dragonfly (Odonata) Specialist Group, writes the chairman, Dr Norman Moore. No country in the world has appreciated dragonflies more than Japan. Species are known by vernacular names and represented in art and mythology. Japan's dragonfly fauna is particularly rich and interesting and there is an active scientific society devoted to its study which produces an excellent journal.

Most dragonfly species, of which there are about 6000 , are found in the tropics and are particularly vulnerable to land-use changes, such as forest clearance, which affect water quality. In fact, says Dr Moore, dragonflies are useful indicators of ecological health. They are also a very ancient group; many have changed little since their contemporaries included the archaeopteryx, and the Group recommends that special studies should be made of the species that are the dragonfly equivalents of the coelacanth, to ensure that these 'living fossils' are saved for posterity. 